\title{
JAJANAN SEHAT PADA ANAK SEKOLAH DASAR NEGERI 204 KOTA JAMBI
}

\author{
Rahmi Dwi Yant ${ }^{(1)}$ Salvita Fitrianti ${ }^{2)}$ Miko Eka Putri ${ }^{3)}$ \\ 1,2,3 Program Studi Ilmu Keperawatan, STIKEs Baiturrahim Jambi \\ email: salvita.fitrianti@gmail.com
}

\begin{abstract}
Children usually forget breakfast and choose to buy snacks at school. Children buy snacks according to their likes without thinking about the ingredients contained in them. Many snacks that do not meet health requirements threaten the health of children throughout 2004 in 164 outbreaks of food poisoning in 25 provinces in 7,366 cases and 51 of them died. Counseling was conducted on December 8, 2018 in SD Negeri 204 Kota Jambi with a total of 31 participants. Outreach results can be obtained by students in grade 5 understanding what is meant by healthy snacks, the benefits of healthy snacks, and the impact of unhealthy snacks. The results of this counseling also introduce students to a sample menu of healthy snacks, a type of healthy food content whose nutritional value is needed for the growth of these students. Conclusion Class 5 students know healthy snacks, benefits and effects of unhealthy snacks, are expected for the next counseling activity to involve parents.
\end{abstract}

Keyword: counseling; children; healthy snacks

\begin{abstract}
ABSTRAK
Anak sekolah biasanya sering melupakan sarapan pagi dan memilih membeli makanan jajanan di sekolah. Anak-anak membeli makanan jajanan menurut kesukaannya tanpa memikirkan bahanbahan yang terkandung di dalamnya . Banyak jajanan yang kurang memenuhi syarat kesehatan sehingga justru mengancam kesehatan anak selama tahun 2004 di seluruh Indonesia telah terjadi kejadian luar biasa (KLB) keracunan makanan sebanyak 164 kejadian di 25 provinsi yang mencakup 7.366 kasus dan 51 diantaranya meninggal dunia. Penyuluhan dilakukan pada tanggal 8 Desember 2018 di SD Negeri 204 Kota jambi dengan Jumlah peserta 31 orang. Hasil Penyuluhan di dapat siswa/siswi kelas 5 mengerti apa yang dimaksud jajanan sehat, manfaat jajanan sehat dan dampak jajanan tidak sehat. Hasil penyuluhan ini juga mengenalkan kepada siswa/siswi contoh menu jajanan sehat, jenis kandungan makanan sehat yang nilai gizinya diperlukan untuk pertumbuhan siswa/siswi tersebut. Kesimpulan Siswa/siswi kelas 5 mengetahui jajanan sehat, manfaat dan dampak dari jajanan tidak sehat, diharapakan untuk kegiatan penyuluhan berikutnya dapat melibatkan orang tua siswa/siswi tersebut.
\end{abstract}

Kata kunci: Penyuluhan; anak; Jajanan sehat

\section{PENDAHULUAN}

Makanan jajanan adalah makanan yang dipersiapkan dan dijual oleh pedagang kaki lima di jalanan dan tempat-tempat keramaian umum lain yang lansung dimakan atau dikonsumsi tanpa pengolahan atau persiapan lebih lanjut. Istilah makanan jajanan tidak jauh dari istilah junk food,fast food, dan street food karena istilah tersebut merupakan bagian dari istilah makanan jajanan (Andriani, 2012).

Makanan jajanan juga merupakan masalah yang perlu menjadi perhatian masyarakat, karena terdapat beberapa makanan jajanan yang tidak higienis 
sehingga sangat beresiko terhadap cemaran yang dapat menggangu kesehatan. Anak sekolah dasar sangat rentan dalam masalah ini karena anak tersebut belum mengerti cara memilih jajanan yang sehat sehingga dapat berakibat buruk pada kesehatannya sendiri. Anak sekolah biasanya sering melupakan sarapan pagi dan memilih membeli makanan jajanan di sekolah. Anak-anak membeli makanan jajanan menurut kesukaannya tanpa memikirkan bahan-bahan yang terkandung di dalamnya (Judarwanto, 2008).

Frekuensi kejadian luar biasa (KLB) keracunan makanan pada anak sekolah meningkat pada tahun 2004. KLB tertinggi terjadi pada anak sekolah dasar (SD) yaitu 19 kejadian dengan jumlah korban sakit sebanyak 575 orang (Sekretariat Jenderal Intelijen Pangan, 2005). Banyak jajanan yang kurang memenuhi syarat kesehatan sehingga justru mengancam kesehatan anak (BPOM. 2003).

Penelitian Djaja (2008) di 3 (tiga) jenis tempat pengelolaan makanan (TPM) menyimpulkan bahwa pedagang kaki lima beresiko 3,5 kali lipat terhadap terjadinya kontaminasi makanan dibandingkan dengan usaha jasaboga, restoran dan rumah makan. Hasil pemantauan BPOM tahun 2011 menunjukkan ada $35.5 \%$ makanan jajanan anak sekolah tidak memenuhi syarat keamanan. Laporan surveilan Direktorat Surveilan dan Penyuluhan Keamanan Pangan BPOM menunjukkan selama tahun 2004 di seluruh Indonesia telah terjadi kejadian luar biasa (KLB) keracunan makanan sebanyak 164 kejadian di 25 provinsi yang mencakup 7.366 kasus dan 51 diantaranya meninggal dunia.

Dikota Jambi sendiri banyak sekali masalah kejadian akibat jajanan atau makanan yang kurang sehat yang dijual pedagang baik itu diluar maupun diarea sekolah. Hasil kajian terbatas yang dilakukan BPOM Provinsi Jambi Tahun 2013 di beberapa Sekolah Dasar (SD) yang ada di Kecamatan Kota Baru Jambi menemukan banyaknya anak sekolah yang mengkonsumsi makanan dan minuman yang mengandung kadar pemanis buatan sakarin dengan tingkat yang tidak aman. Anak-anak SD yang diteliti, ditemukan konsumsi sakarin sebesar $12,2 \%$ dari nilai ADI (acceptable daily intake).

Maka dari itu penulis tertarik melaksanakan kegiatan penyuluhan tentang "Jajanan Sehat Pada Anak Sekolah Dasar". Kegiatan ini dilaksanakan di Sekolah Dasar Negeri 204 Kota Jambi.

\section{TARGET DAN LUARAN}

\section{Target}

Target yang diharapkan dalam kegiatan ini, yaitu:

a. Siswa/I diharapkan mampu memilih jajanan yang sehat

b. Siswa/I diharapkan mampu mengetahui manfaat jajan sehat dan jajanan tidak sehat

c. Siswa/I diharapkan mampu menjaga atau meningkatkan kesehatannya secara mandiri.

2. Luaran

Luaran yang diharapkan dari kegiatan ini yaitu :

a. Tersedianya tempat jajanan atau kantin yang menyediakan jajanan sehat untuk siswa.

b. Sekolah dapat menertibkan tempat jajanan yang tidak memenuhi syarat

\section{METODE PELAKSANAAN}

1. Waktu dan Tempat

Kegiatan ini dilakukan pada bulan Nopember 2018 di Ruang Kelas SDN 204.

\section{Tujuan}

a. Memberikan pengetahuan kepada siswa tentang pengertian jajanan sehat, ciri-ciri jajanan sehat, manfaat jajanan sehat dan dampak jajanan tidak sehat 
b. Mengajak siswa untuk mengenali menu jajanan sehat dan bergizi

c. Mendemonstrasikan jajanan sehat yang berguna bagi tubuh (bergizi)

3. Sasaran

Siswa/siswi SD Negeri 204 Kota Jambi Kelas 5

4. Kontribusi Peserta

a. Peserta yang hadir siswa/siswi SD Negeri 204 kelas 5 sebanyak 31 orang

b. Peserta mengikuti kegiatan dari awal sampai akhir

c. Peserta aktif dan antusias mendengar penyuluhan dan menjawab pertanyaan yang diberikan.

5. Pelaksanaan Kegiatan Pengabdian

a. Acara penyuluhan dimulai jam 11.0012.00 WIB bertempat di ruang kelas SD Negeri 204 Kota Jambi

b. Jumlah peserta yang hadir sebanyak 31 orang yang terdiri dari: 30 orangsiswa/siswi, 1 orang guru

c. Semua struktur organisasi yang terlibat dalam acara penyuluhan telah berperan sesuai tanggung jawab yang diberikan yaitu sebagai moderator, presenter, observer, fasilitator dan notulen

d. Selama pelaksanaan peserta berperan aktif dan antusias dalam menjawab pertanyaan yang diajukan

e. Semua peserta yang hadir mengikuti kegiatan dari awal sampai akhir kegiatan yang berjumlah 31 orang

\section{HASIL DAN PEMBAHASAN}

Kegiatan Pengabdian kepada Masyarakat melalui penyuluhan tentang jajanan sehat pada siswa/siswi kelas 5 SD Negeri 204 Kota Jambi berlangsung selama 60 menit. Setelah diberikan kegiatan penyuluhan siswa/siswi kelas 5 mengerti apa yang dimaksud jajanan sehat, manfaat jajanan sehat dan dampak jajanan sehat.
Hasil penyuluhan ini juga mengenalkan kepada siswa/siswi contoh menu jajanan sehat, jenis kandungan makanan sehat yang nilai gizinya diperlukan untuk pertumbuhan siswa/siswi tersebut.

Jajanan sehat dan yang mempunyai nilai gizi yang baik akan menghindari siswa/siswi kelas 5 khususnya dan siswa SD Negeri 204 secara keseluruhan dari kemungkinan kejadian keracunan makanan maupun kejadian sakit yang disebabkan oleh jajanan yang tidak sehat seperti diare.

\section{KESIMPULAN DAN SARAN}

\section{Kesimpulan}

1. Siswa/siswi kelas 5, 95\% mampu menjelaskan pengertian jajanan sehat

2. Siswa/siswi kelas 5, 97\% mampu menyebutkan ciri-ciri jajanan sehat.

3. Siswa/siswi kelas 5, 95\% mampu menjelaskan manfaat dan dampak jajanan sehat

\section{Saran}

1. Untuk kegiatan penyuluhan yang ada di SD Negeri 204, untuk kedepannya dapat melibatkan orang tua/ wali sehingga dapat memberikan informasi juga kepeada orang tua tentang jajanan sehat tersebut

2. Bagi pemberi penyuluhan selanjutnya. diharapkan dapat melakukan melakukan kegiatan pengabdian kepada masyarakat dengan tema lain yang berhubungan langsung dengan siswa/siswi SD.

\section{DAFTAR PUSTAKA}

Andriani, M. (2012). Pengantar Gizi Masyarakat. Jakarta: Kencana Prenada Grup

Judarwanto, W (2008) Prilaku Makan Anak Sekolah. Diakses tanggal 31 Mei 2014. $h t t p: / / w w w$. 
Litbang.depkes.go.id/aktual/anak/makana n140206.htm

BPOM RI (2003). Jajanan Anak Sekolah, Jakarta

Djaja,I.M. (2008). Kontaminasi E.Coli Pada Makanan Dati Tiga Jenis Tempat PengelolaanMakanan (TPM) di Jakarta Selatan, Makara Kesehatan 12 (1): 36-41

BPOM Provinsi Jambi, (2013). Data Persentase Konsumsi Sakarin Jambi Sehat 